tion in the United States demonstrated how linking consumption to production has stimulated recent research on class construction. Alan Berolzheimer examined how social scientists produced homogenized models of consumption and "mass culture" in the early twentieth century. Visions of consumer society structured the decisions of retailers and employers, as Meg Jacobs demonstrated in an investigation of department store owner Edward Filene. They also influenced workers in the cooperative movement, as Stephen Milim showed in a paper on cooperative housing in New York City. Discussant Dana Frank praised the panelists' demonstrations of how consumption, as ideology and practice, contributed to workers' selfidentification as members of the middle class during the interwar period. She cautioned, however, that workers' acquisition of property and producers' efforts to stimulate consumption must also be understood as material processes of capital accumulation and class transformation. Discussion forecasted a revised analysis of consumption in American history, one in which the approaches proposed by the panelists would succeed in politicizing the present understanding of consumption as a feature of a generalized "mass culture" developing between the world wars.

More than a dozen conferees attended the Labor Network meeting to plan sessions for the next SSHA conference. The Network chose to feature panels exploring the value of interdisciplinary approaches and crossnational comparisons. Comparative panels on anarchism, race and ethnicity, homework, rural labor, and the experiences of dockworkers were proposed. Panels on work in the borderlands of the United States and Mexico, on migrant labor on the U.S. East Coast, and on transnational constructions of race, ethnicity, and culture were also recommended, and these sessions will anchor the discussion of labor and working-class history at the 1996 conference in New Orleans (October 10-13).

\title{
1996 American Historical Association Meeting
}

\author{
Donna Harsch \\ Carnegie Mellon University \\ Marta V. Vicente \\ Johns Hopkins University \\ Thomas Winter \\ University of Cinncinati
}

The 110th meeting of the American Historical Association, held January 4-7 in Atlanta, featured only a few panels and a scattering of isolated 
papers on the historical experience of labor. Historians of medicine, education, and violence were as well or better served by the program, which focused this year on the theme of citizenship. Modern European labor history was especially scarce; the few papers presented focused almost exclusively on the period from 1890 to 1930 and on northwestern Europe. They were typically as concerned with gender as with class issues and analyzed the cultural practices of workers without examining relationships on the shop floor.

That culture and representations, not society and actions, took center stage was shown by panel titles like "Class and Patriotism in the Great War: British Representations, 1914-1918." Here, three young scholars explored the reasons why women and workers volunteered for the British Armed Forces. Based on her reading of writings by working-class female volunteers, Krisztina Robert (University of Houston) argued that female volunteers had embraced patriotism and were determined to participate actively in the war. She rejected an older claim that working-class volunteers were either enticed by good wages or duped by patriotic propaganda. Women in the Women's Army Auxiliary Corps were less well paid than munitions workers, and they had to brave conservative aspersions cast on their femininity and socialist cries of class betrayal. In Robert's view, military service promoted women's integration into society as active citizens. Working-class women in particular broke from class values and identified with other women, though not as self-conscious feminists.

Janet Watson (Stanford University) examined contemporary interpretations of women's war volunteer work and military service. Young men and women from bourgeois families believed that women's contributions to the war effort (as nurses, for example) were as significant and selfsacrificing as their brothers' soldiering. The public viewed working-class volunteers less positively than those middle-class women who assumed more "feminine" functions. Male commentators and middle-class women impugned the seriousness of "frivolous" worker-volunteers who, they assumed, did not understand the significance of their military service.

David Silbey (Duke University) sought to explain the paradox that workers volunteered at a high rate at the very outset of the war despite strong class antagonisms. Examining hundreds of memoirs, diaries, and postwar interviews, he found that the motivations of these volunteers were complex-jingoism activated hatred of German authoritarianism, adventurism complemented aspirations for social advancement, and solidarity with the front-line soldier merged with the desire for jobs. Volunteers expressed both class and national values. Like Robert, Silbey rejected interpretations of workers" patriotism as "false consciousness" and argued that they had absorbed nationalist values. Both presenters maintained, however, that workers refashioned those values to reflect their social experience.

Another panel, "Constructing Socialist Meanings: Gender, Class, and 
the Nation in Imperial and Weimar Germany," considered the intersection between gender and class identities in the organized labor movement. Mary Jo Maynes (University of Minnesota) compared the construction of militant identities for men and women in German social democracy between 1890 and 1914. Her examination of the back sections of two social democratic newspapers revealed that they presented grassroots activism as the work of both male and female militants. Maynes's evidence did not refute claims that patriarchical models and male heros dominated the movement; rather, she argued, it showed that women were offered a model to structure their self-image and identities as "comrades."

Donna Harsch (Carnegie Mellon University) considered the contrast between women's marginalized position in the Social Democratic party (SPD) and the self-confidence, courageous dissidence, and grassroots popularity of individual women in the party in Munich during the 1920s. Her examination of police reports on social democratic gatherings showed that these women considered themselves representatives of women's rights in the SPD, yet stepped forward in local party life mainly as devotees of proletarian culture and internal party democracy, thereby gaining the support of militant male dissidents. Nonetheless, their popularity did not produce a higher profile in the party for women. They only gained a hearing when they spoke in defense of class solidarity and a traditional culture that was overwhelmingly male, both in fact and in fantasy.

In his talk on militancy, masculinity, and the meaning of class in the Weimar Communist party (KPD), Eric Weitz (St. Olaf College) contrasted the KPD's emancipatory program for women with the masculine rhetoric, metaphors, and images with which its press propagated its vision of class. Photos in mass circulation weeklies celebrated male labor in heavy industry, and male workers as fighters for proletarian emancipation. Communists defined Kampf as physical struggle and, indeed, as street battles and armed revolution. Shaped by its battles with National Socialists, the KPD's masculine tone and militaristic ethos developed into a "culture of physical violence" by the early 1930s. In contrast to these images of male workers, no unified, powerful image of the "proletarian woman" emerged. Instead, women were portrayed as oppressed workers, depressed mothers, or sexually expressive "new women"-but not as active participants in the struggle for socialism.

At least one panel broke out of the regional and temporal boundaries limiting the overall program. As Chair John Tone (Georgia Institute of Technology) pointed out, "Artisan Families and Industrial Development: Conflict or Complement?" highlighted the process of industrialization for periods and places (Italy, Spain, and Holland) not frequently represented in panels at large conferences. Luca Molà (Johns Hopkins University), presenting “'Not Under the Same Roof': Conflicts between Merchants and Artisans in the Silk Industry of Sixteenth-Century Venice," showed that industrial development was a result of changes in the way artisan families 
organized production and trade rather than a result of the actions of individual entrepreneurs. Responding to the expansion of silk cloth consumption, Venetian silk masters began to market their own production and to enroll members of their families in different commercial and industrial guilds, thus evading the ban on individuals belonging to more than one corporation. Masters' families adapted to the growing demand for silk cloths by placing more family members in commerce and manufacture. These practices challenged the authority of silk merchants and their manufacturing monopoly.

Such change did not occur only in times of economic growth. In "An Alternative Road to Industrialization: Guilds and Family in Barcelona, 1600-1800," Luis Corteguera (University of Kansas) and Marta Vicente (Johns Hopkins University) showed how Barcelona artisans in the wool industry adapted to economic contraction in the early 1600 s without succumbing to "capitalist" forms of production. This allowed artisan production, centered on the family, to thrive into the early $1800 \mathrm{~s}$. In the late 1700 s, artisan families provided laborers and factory owners for the city's incipient industrialization of the cotton industry. Artisan families also took in homework, enabling factories to increase production in busy periods without having to invest in additional equipment or hire more factory workers.

Joyce Mastboom (Cleveland State University) presented "Families, Flexibility and Economic Change: the Eastern Achterhoek in the Netherlands," which also suggested reasons for the flexible character of artisan production and its relation to economic development in the Netherlands. Regional inheritance patterns, gendered division of labor, and live-in servants gave families enough flexibility to adapt when local rural manufacturing first expanded and then industrialized. The ability to adjust and stay in agriculture at a time when factory production had begun and farming itself was commercializing can be traced in large part to the local traditional family structure and the families' practice of by-employment.

These papers analyzed industrial growth as a cultural process as much as an economic one, noted discussant Leonard Rosenband (Utah State University). The key was not who had the skill but who had the knowledge. As revisions of E. P. Thompson's "moral economy of the crowd," the papers presented workers as rational agents participating in market activities. Artisans and peasants, therefore, were protagonists in the industrialization process. Though one can find innovation in these families' behavior, he cautioned, one should also consider that they were sources of inertia.

For historians of workers and work in America, the meeting had two interesting panels to offer. Both demonstrated historians' continuing interest in gender issues. The panel "Slaves at War: Gender, Race, and Politics during the American Revolution and Civil War in the South Carolina Lowcountry" featured Edward Pearson of Franklin and Marshall College presenting "Ideology, Slavery, and Revolution in the Eighteenth-Century 
South Carolina Lowcountry," and Leslie Schwalm of the University of Iowa on "Slavery's Wartime Crisis: Slaves, Slavery, and Civil War in the South Carolina Lowcountry." Pearson showed how slaves, especially in and around Charleston, assimilated the revolutionary radicalism spreading among white South Carolinians. When British royal authority evaporated in 1775, they tested the new boundaries of authority. The Revolution, he argued, planted the roots of continuing resistance and restiveness throughout the antebellum era, such as the Denmark Vesey rebellion in 1822 .

Placing slave women at the center of her story, Leslie Schwalm explored how slaves, who were central to the Confederate war effort, challenged the "peculiar institution" in South Carolina during the Civil War. As domestic servants, they found opportunities for resistance in the daily routines of the planters' households.

A panel on "Gender and Identity in United States Maritime Cultures" also dealt with labor and labor-related issues. Lisa N. Norling of the University of Minnesota presented "Femininity Afloat: Nineteenth-Century New England Women at Sea," and Susan A. Eacker of Miami University delivered "Masculinity, Matriarchy, and Maritime Culture: Gender Identity and Class Consciousness in a Florida Fishing Village, 1890-1990." Norling examined the lives of captains' wives, who frequently joined their husbands at sea after 1840 . The lives of these women. isolated for years in shipbound communities of working men, cast new light on gender dynamics and the ideology of separate spheres in nineteenth-century America, Norling argued. In their attempts to live up to conjugal ideals, captains' wives redefined the concept of home as the domestic sphere, founded on women's uplifting influence. Resented by the common sailors and restricted from moving any further than the main mast, however, these women could not carry their domestic ideology into the public realm, as women did on the mainland.

Susan Eacker examined the role of women's work in the small Florida maritime community of Cortez. Whereas the sea is often associated with the female. Eacker pointed out that women are generally marginalized in the historiography of maritime cultures and seafaring communities. Eacker argued that occupational and gender dynamics of Cortez's economy and culture hinged on women's labor. She asserted that the hypermasculinity and the working-class consciousness of seafaring workers was founded on women's paid and unpaid labor. In the twentieth century, women's contribution to the households of Cortez helped to maintain a male-dominated work culture, distinguished by precapitalist traditions. 